\title{
THERMAL STABILITY OF NOVEL MULTILAYER LANTHANUM ZIRCONATE BASED THERMAL BARRIER COATINGS
}

Xingye Guo ${ }^{\mathrm{a}}$, Zhe Lu' ${ }^{\mathrm{b}}$, Yeon-Gil Jung ${ }^{\mathrm{b}}$, Li Lic ${ }^{\mathrm{c}}$, James Knappc ${ }^{\mathrm{c}}$, Jing Zhang*,

${ }^{a}$ Department of Mechanical Engineering, Indiana University-Purdue University Indianapolis, IN 46202, USA

b School of Nano and Advanced Materials Engineering, Changwon National University, Changwon, Gyeongnam 641-773, Republic of Korea

c Praxair Surface Technologies Inc., Indianapolis, IN 46222, USA

*Corresponding author: jz29@iupui.edu

Keywords: Lanthanum zirconate, thermal barrier coatings, thermal cycling, thermal shock

\begin{abstract}
$\mathrm{La}_{2} \mathrm{Zr}_{2} \mathrm{O}_{7}$ is one of the proposed next generation thermal barrier coating materials due to its low thermal conductivity and superior high temperature stability. In this work, $\mathrm{La}_{2} \mathrm{Zr}_{2} \mathrm{O}_{7}$ and conventional $8 \mathrm{wt} \%$ yttria stabilized zirconia (8YSZ) coatings were deposited using plasma spray technique. Both single-layer $\mathrm{La}_{2} \mathrm{Zr}_{2} \mathrm{O}_{7}$ and double-layer $8 \mathrm{YSZ}_{2} \mathrm{La}_{2} \mathrm{Zr}_{2} \mathrm{O}_{7}$ coating architectures were designed in the matrix for evaluation. Heat treatment, thermal cycling, and thermal shock tests were conducted on the samples to evaluate their thermal stability. All the $\mathrm{La}_{2} \mathrm{Zr}_{2} \mathrm{O}_{7}$ coats were delaminated in the furnace cycle test in less than 20 cycles. This is because residual thermal stresses accumulated during thermal cycling. In the heat treatment and the jet engine thermal shock (JETS) tests, the SCL $\mathrm{La}_{2} \mathrm{Zr}_{2} \mathrm{O}_{7}$ and DCL dense $8 \mathrm{YSZ} / \mathrm{La}_{2} \mathrm{Zr}_{2} \mathrm{O}_{7}$ coatings were fully delaminated. In contrast, the DCL porous $8 \mathrm{YSZ} / \mathrm{La}_{2} \mathrm{Zr}_{2} \mathrm{O}_{7}$ coating sample only partially delaminated on the edge. This is because of the porous 8YSZ layer provides strain compliance. The findings will help to propose efficient thermal barrier coating systems.
\end{abstract}

\section{INTRODUCTION}

Thermal barrier coatings (TBCs) provide thermal insulation to metallic substrate of gas turbine engine parts. The TBCs allow the gas turbine designer to increase the temperature and consequently the engine efficiency[1, 2]. TBC systems are typically multi-layer type coatings, which consist of a metallic bond coat and at least one ceramic topcoat layer. The metallic bond coat protects the superalloy substrate from oxidation and corrosion, and improves the adhesive bond between the ceramic topcoat and the superalloy substrate [3]. The bond coat has stress compliance to minimize the thermal-expansion-mismatch stresses between the superalloy substrate and the ceramic topcoat in heating and cooling process [1]. The ceramic topcoat has an extremely lower thermal conductivity than superalloy substrate, which establishes a large temperature drop (more than $100 \mathrm{~K}$ ) in the ceramic topcoat layer [3]. Currently, the most preferred technique to fabricate thermal barrier coatings is air plasma spray (APS) process, because it is capable of producing durable coatings economically. TBC powders are fed into the high temperature arc plasma, where the powders melt into "splat" as they are propelled to the 
target substrate. Alternatively, the electron beam-physical vapor deposition (EB-PVD) process produces columnar structure, which has outstanding test lifetime $[4,5]$.

The criteria for TBCs material selection include high melting point, low thermal conductivity, high coefficient of thermal expansion, good thermal and chemical stability, no phase change, and low sintering activity. Nowadays, state-of-the-art TBCs are 8YSZ ceramic topcoat with a NiCrAlY bond coat. The 8YSZ material has a significantly lower thermal conductivity than the metallic substrate $[6,7]$. However, the maximum surface temperatures of $8 Y S Z$ coating a limited to $1473 \mathrm{~K}$ for long time operation, because of the phase transformation and the sintering of the coating [7]. So $\mathrm{La}_{2} \mathrm{Zr}_{2} \mathrm{O}_{7}$ TBCs coats have been proposed as an alternative TBCs material operated at higher temperatures. $\mathrm{La}_{2} \mathrm{Zr}_{2} \mathrm{O}_{7}$ has an even lower thermal conductivity than that of $8 \mathrm{YSZ}$, and it has no phase change from room temperature to its melting temperature (2573 K) [8-10]. The coefficient of thermal expansion of $\mathrm{La}_{2} \mathrm{Zr}_{2} \mathrm{O}_{7}$ is $9.0 \sim 10.0 \times 10^{-}$ ${ }^{6} \mathrm{~K}^{-1}$, which is a little bit lower than that of $8 \mathrm{YSZ}\left(10 \sim 11 \times 10^{-6} \mathrm{~K}^{-1}\right)[8,10,11]$.

EB-PVD produced $\mathrm{La}_{2} \mathrm{Zr}_{2} \mathrm{O}_{7}$ coating and APS produced dense $\mathrm{La}_{2} \mathrm{Zr}_{2} \mathrm{O}_{7}$ and $8 \mathrm{YSZ}$ multi-layer coatings were investigated by other researchers. Bobzin et al. studied single-ceramic (SCL) and double-ceramic layer (DCL) EB-PVD TBC top coats consisting of $\mathrm{La}_{2} \mathrm{Zr}_{2} \mathrm{O}_{7}$, $\mathrm{Gd}_{2} \mathrm{Zr}_{2} \mathrm{O}_{7}$ and $7 \mathrm{wt} \%$ YSZ. The temperature-dependent phase behavior and change of thermal conductivity of SCL and DCL top coats were investigated [12]. Vassen et al. studied thermal and mechanical properties and thermal stability of hot pressed fully dense $\mathrm{La}_{2} \mathrm{Zr}_{2} \mathrm{O}_{7}$ materials [8]. Cycling performances between double and SCL $\mathrm{La}_{2} \mathrm{Zr}_{2} \mathrm{O}_{7}$ TBC samples were compared. It concluded that highly dense $\mathrm{La}_{2} \mathrm{Zr}_{2} \mathrm{O}_{7}$ material has a lower thermal conductivity than that of YSZ. The DCL TBC samples, which were composed of $\mathrm{La}_{2} \mathrm{Zr}_{2} \mathrm{O}_{7}$ and YSZ, have similar results with SCL YSZ coating at temperatures below $1300{ }^{\circ} \mathrm{C}$. At higher temperatures, the DCL TBCs samples revealed excellent thermal cycling behavior [8, 10, 13]. Zhu et al. investigated the durability and failure mechanism of plasma-sprayed $\mathrm{La}_{2} \mathrm{Zr}_{2} \mathrm{O}_{7} /$ mullite/Si coatings on mullite/SiC or $\mathrm{SiC} / \mathrm{SiC}$ ceramic matrix composite substrates at $1650{ }^{\circ} \mathrm{C}$ under thermal gradient cyclic conditions [14]. The $\mathrm{La}_{2} \mathrm{Zr}_{2} \mathrm{O}_{7}$ coating showed significant thermal conductivity increase in the laser flux condition at $1575{ }^{\circ} \mathrm{C}$, indicating the coating was undergoing substantial sintering at elevated temperatures. The plasma-sprayed $\mathrm{La}_{2} \mathrm{Zr}_{2} \mathrm{O}_{7} /$ mullite/Si systems on $\mathrm{SiC}$ substrate showed severe spallation on heating under high heat flux $\left(95-100 \mathrm{~W} / \mathrm{cm}^{2}\right)$ at $1650{ }^{\circ} \mathrm{C}$ [14].

The goal of this work is to study the thermal stability of SCL and DCL porous $\mathrm{La}_{2} \mathrm{Zr}_{2} \mathrm{O}_{7}$ coats. In this work, three types of SCL and DCL $\mathrm{La}_{2} \mathrm{Zr}_{2} \mathrm{O}_{7}$ and $8 Y S Z$ structures were deposited. Heat treatment, cyclic furnace cycle test and jet engine thermal shock test were conducted for the TBC samples. The failure mechanisms of these TBC systems were discussed.

\section{METHODS}

SCL $\mathrm{La}_{2} \mathrm{Zr}_{2} \mathrm{O}_{7}$ and DCL $8 \mathrm{YSZ}_{2} \mathrm{La}_{2} \mathrm{Zr}_{2} \mathrm{O}_{7}$ ceramic coatings were deposited onto a NiCrAlY bond coat (thickness of $229 \mu \mathrm{m}$ ) using APS technique. Haynes 188 superalloy round buttons with 1 inch diameter and 1/8 inch thickness were used as the substrate. The porosity of porous $8 \mathrm{YSZ}$ and porous $\mathrm{La}_{2} \mathrm{Zr}_{2} \mathrm{O}_{7}$ coating layers is about $12 \%$. The dense $8 \mathrm{YSZ}$ has a porosity less than $8 \%$. Three types of samples are listed in Table 1. 
Table 1: List of $\mathrm{La}_{2} \mathrm{Zr}_{2} \mathrm{O}_{7}$ and YSZ samples

\begin{tabular}{|c|c|c|}
\hline Sample & Top coat & Top coat thickness \\
\hline 1 & SCL porous $\mathrm{La}_{2} \mathrm{Zr}_{2} \mathrm{O}_{7}$ & $432 \mu \mathrm{m}$ \\
\hline 2 & DCL porous 8YSZ/porous $\mathrm{La}_{2} \mathrm{Zr}_{2} \mathrm{O}_{7}$ & $127 / 305 \mu \mathrm{m}$ \\
\hline 3 & DCL dense 8YSZ/porous $\mathrm{La}_{2} \mathrm{Zr}_{2} \mathrm{O}_{7}$ & $127 / 305 \mu \mathrm{m}$ \\
\hline
\end{tabular}

Furnace heat treatment experiments were conducted for all of the as sprayed coating samples in argon atmosphere at $1353 \mathrm{~K}\left(1080{ }^{\circ} \mathrm{C}\right)$ for 4 hours. Microstructure images of heat treated samples were taken using a scanning electron microscope (SEM, JEOL Model JSM5610, Japan).

The FCT experiments were conducted between high temperature $1366 \mathrm{~K}\left(1093{ }^{\circ} \mathrm{C}\right)$ and room temperature. In each cycle, samples were heated at $1366 \mathrm{~K}$ for 50 minutes, and then cooled by compressed air for 10 minutes.

The JETS experiments create a large temperature gradient (several hundred degrees Celsius) across the TBC layer $[15,16]$. This experiment impacts mainly the ceramic layer and bond coat layer thermomechanically [16]. In this work, the TBC samples were heated at $1505 \mathrm{~K}$ $\left(1232{ }^{\circ} \mathrm{C}\right)$ for $20 \mathrm{~s}$. Then, the TBC samples were cooled by compressed nitrogen jet for $20 \mathrm{~s}$ to provide a maximum thermal gradient. Thereafter the samples were cooled by ambient cooling for $40 \mathrm{~s}$. The heating and cooling cycles were repeated until cracks or spallation were spotted on the TBC surface. Both the front and back surface temperatures were measured using pyrometer.

\section{RESULTS AND DISCUSSION}

\section{Heat Treatment Tests}

After 4 hours of heat treatment, the SCL porous $\mathrm{La}_{2} \mathrm{Zr}_{2} \mathrm{O}_{7}$ and the DCL dense $8 \mathrm{YSZ} / \mathrm{La}_{2} \mathrm{Zr}_{2} \mathrm{O}_{7}$ coatings were fully delaminated. However, DCL porous $8 \mathrm{YSZ} / \mathrm{La}_{2} \mathrm{Zr}_{2} \mathrm{O}_{7}$ coating only delaminated on the edge, due to the CTE difference between porous 8YSZ and dense 8YSZ. Porous 8YSZ has a lower CTE than that of dense 8YSZ. As a result, the thermal stress between $\mathrm{La}_{2} \mathrm{Zr}_{2} \mathrm{O}_{7}$ and porous $8 \mathrm{YSZ}$ is lower than that between $\mathrm{La}_{2} \mathrm{Zr}_{2} \mathrm{O}_{7}$ and dense 8YSZ. Figure 1 shows the SEM images of the heat treated TBC samples. From the microstructure images, all the delamination occurred in the area of $\mathrm{La}_{2} \mathrm{Zr}_{2} \mathrm{O}_{7}$ coating layer that was close to the interface between $\mathrm{La}_{2} \mathrm{Zr}_{2} \mathrm{O}_{7}$ and bond coat (Figure $1 \mathrm{a}$ ), between $\mathrm{La}_{2} \mathrm{Zr}_{2} \mathrm{O}_{7}$ and porous $8 \mathrm{YSZ}$ (Figure 1b) and between $\mathrm{La}_{2} \mathrm{Zr}_{2} \mathrm{O}_{7}$ and dense $8 \mathrm{YSZ}$ (Figure 1c). However, the porous and dense 8YSZ coating layers were all intact. The fracture toughness of $\mathrm{La}_{2} \mathrm{Zr}_{2} \mathrm{O}_{7}$ coating is about $1.1 \mathrm{MPa} \cdot \mathrm{m}^{1 / 2}$, which is lower than that of $8 \mathrm{YSZ}\left(2.0 \mathrm{MPa} \cdot \mathrm{m}^{1 / 2}\right)[8,18]$. So $\mathrm{La}_{2} \mathrm{Zr}_{2} \mathrm{O}_{7}$ layer is weaker than $8 \mathrm{YSZ}$ layer. 


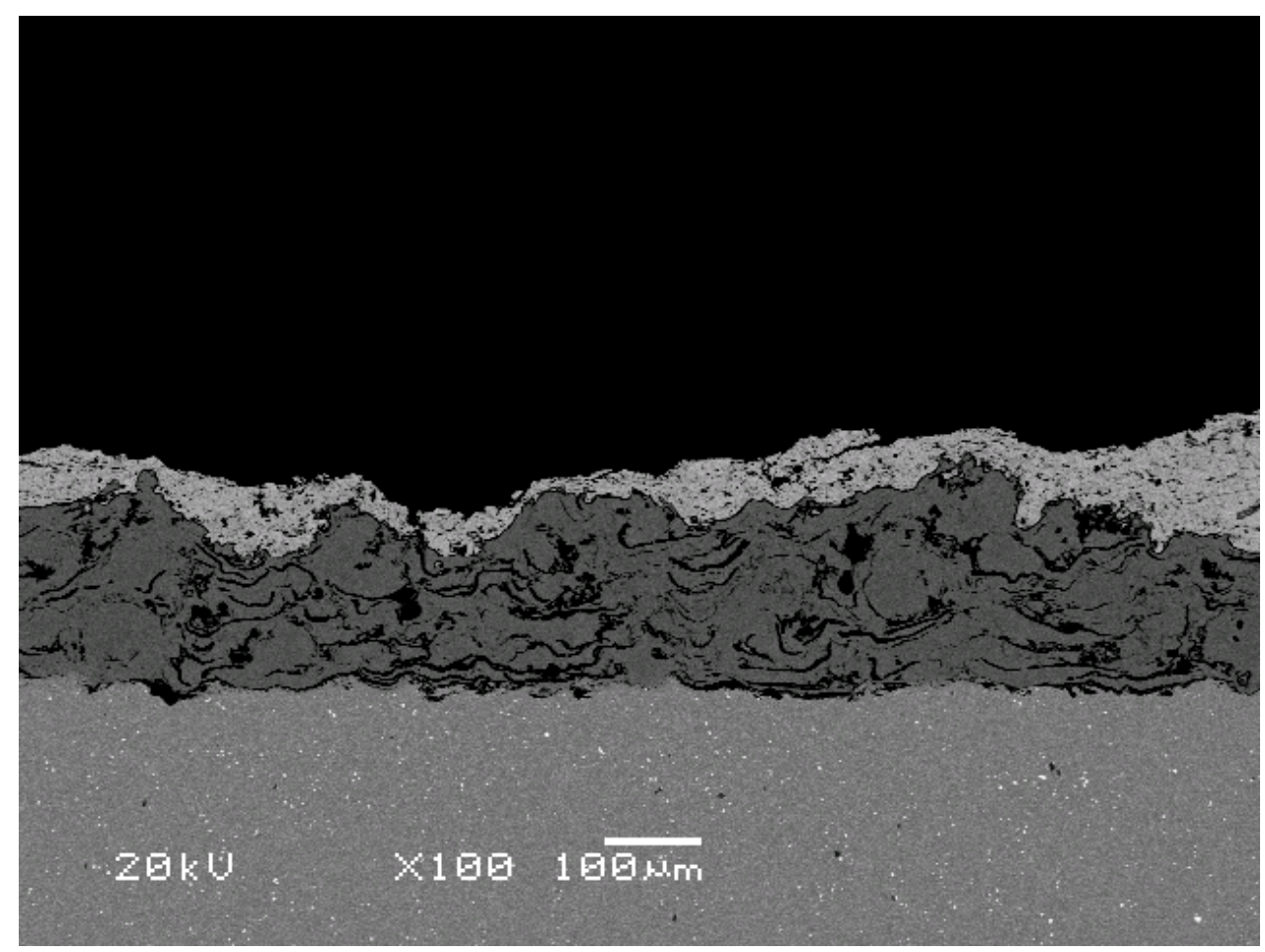

(a)

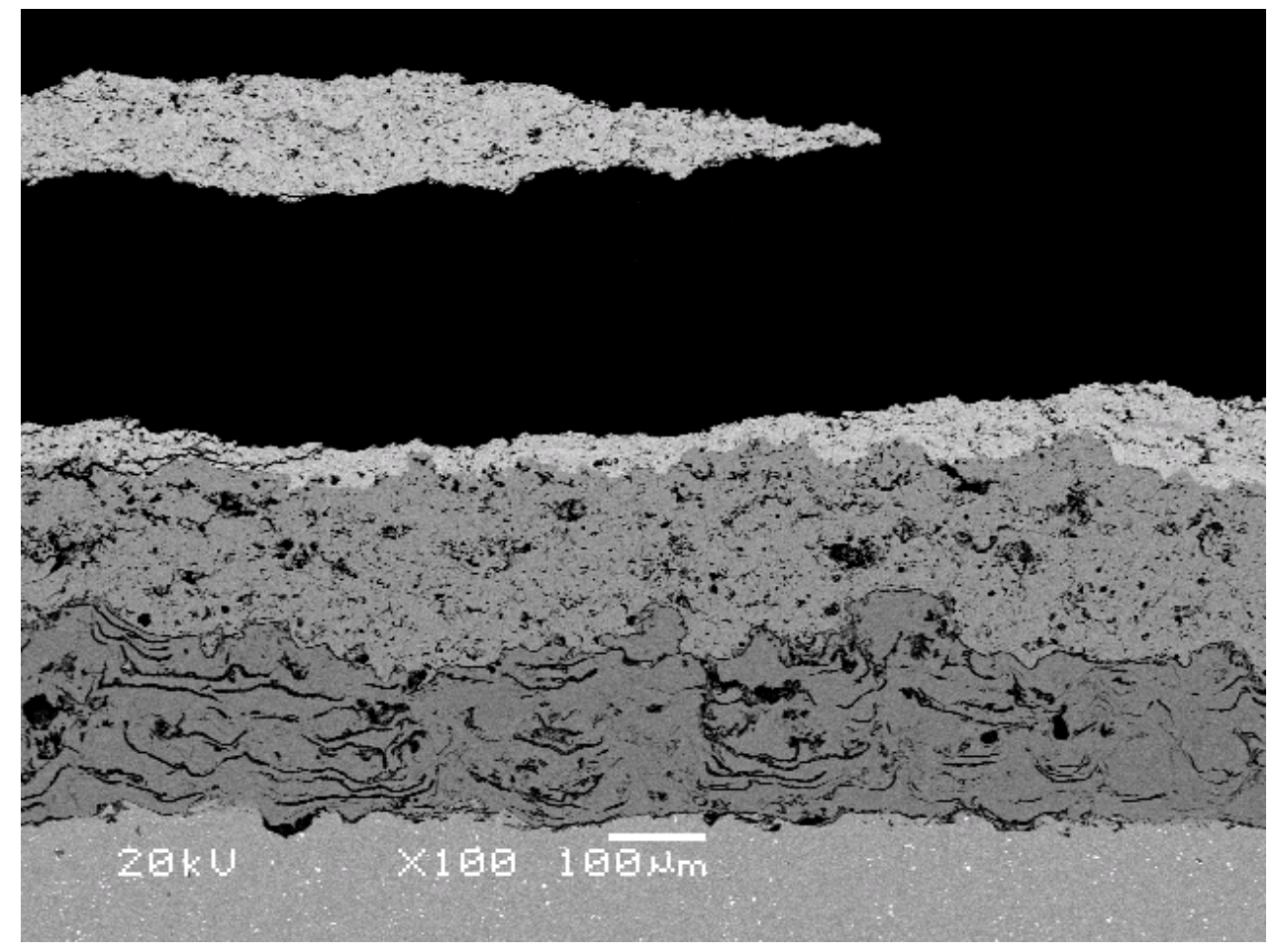

(b) 


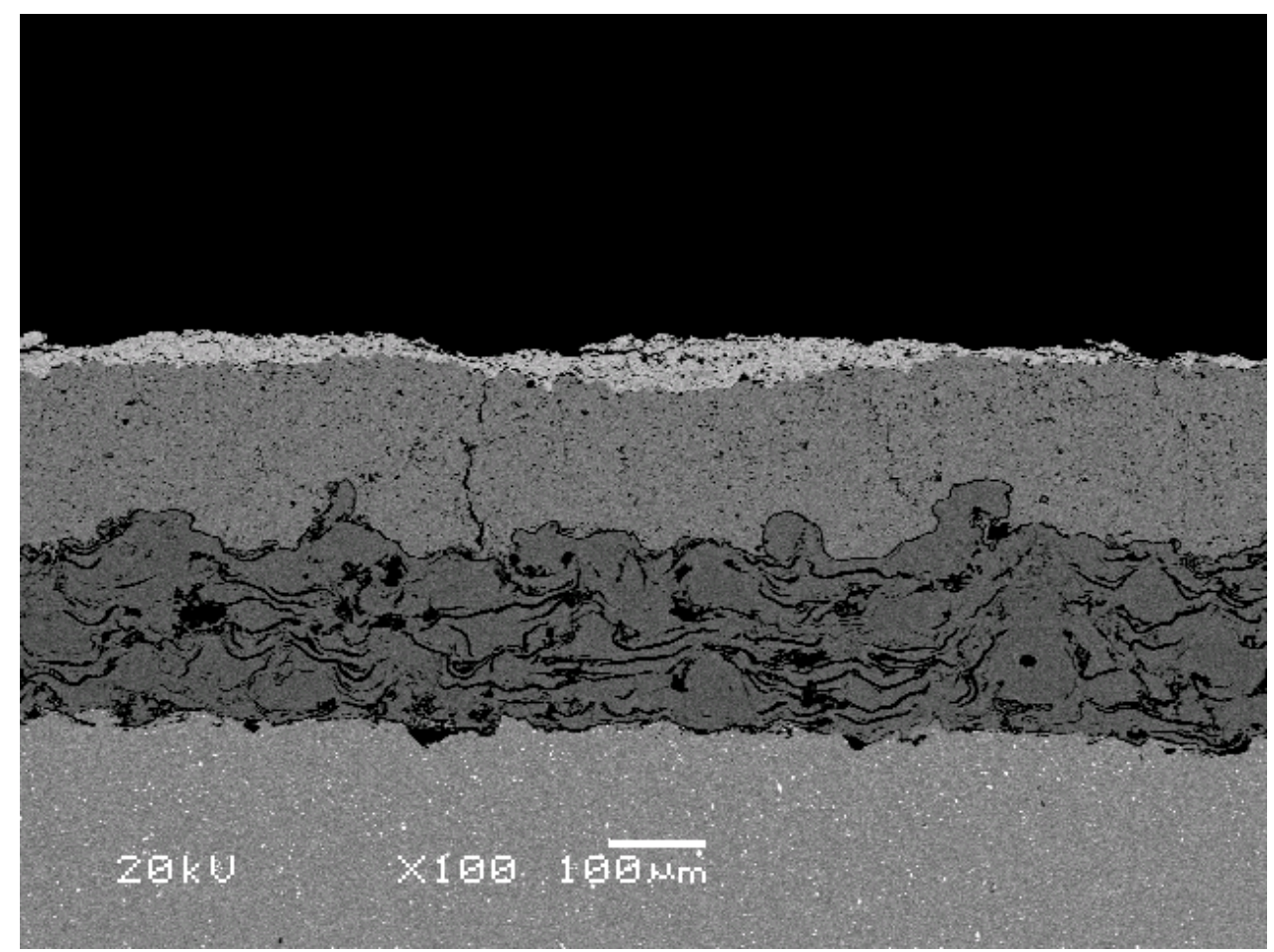

(c)

Figure 1: SEM images of cross-section views of heat treated samples (a) SCL porous $\mathrm{La}_{2} \mathrm{Zr}_{2} \mathrm{O}_{7}$ coating; (b) DCL porous 8YSZ/ $\mathrm{La}_{2} \mathrm{Zr}_{2} \mathrm{O}_{7}$ coating, and (c) DCL dense 8YSZ/ $\mathrm{La}_{2} \mathrm{Zr}_{2} \mathrm{O}_{7}$ coating.

\section{Furnace Cycle Tests}

All $\mathrm{La}_{2} \mathrm{Zr}_{2} \mathrm{O}_{7}$ coats layers were delaminated in the first 20 cycles in the FCT experiments. However, no significant delamination occurred in porous and dense 8YSZ sublayers in DCL samples after 2000 cycles. Because the coefficient of thermal expansion (CTE) of $\mathrm{La}_{2} \mathrm{Zr}_{2} \mathrm{O}_{7}$ (9$\left.10 \times 10^{-6} / \mathrm{K}\right)$ is lower than that of $8 Y S Z\left(10-11 \times 10^{-6} / \mathrm{K}\right)$, and bond coats have even higher CTE (about $15 \times 10^{-6} / \mathrm{K}$ ). The CTE difference between $\mathrm{La}_{2} \mathrm{Zr}_{2} \mathrm{O}_{7}$ and bond coat is larger than that between 8YSZ and bond coat, which leads to higher thermal stresses in $\mathrm{La}_{2} \mathrm{Zr}_{2} \mathrm{O}_{7}$ layers [10, 17]. The failure is ultimately occurred due to the large residual stress at the interface between $\mathrm{La}_{2} \mathrm{Zr}_{2} \mathrm{O}_{7}$ and sublayer.

\section{Jet Engine Thermal Shock Tests}

In the JETS experiments, the SCL $\mathrm{La}_{2} \mathrm{Zr}_{2} \mathrm{O}_{7}$ coating sample was fully delaminated in 40 cycles. Figure 2 (a) shows the optical image of the SCL $\mathrm{La}_{2} \mathrm{Zr}_{2} \mathrm{O}_{7}$ coating after JEST experiments. The delamination occurred at the interface between the bond coat and topcoat. Figure 2 (b) shows that the DCL dense $8 \mathrm{YSZ}_{2} \mathrm{La}_{2} \mathrm{Zr}_{2} \mathrm{O}_{7}$ coating sample was partially delaminated on the edge after 2000 cycles. Therefore, the porous $8 Y S Z / \mathrm{La}_{2} \mathrm{Zr}_{2} \mathrm{O}_{7}$ coating sample has the best thermal stability in all samples. Figure 2 (c) shows the DCL dense $8 \mathrm{YSZ} / \mathrm{La}_{2} \mathrm{Zr}_{2} \mathrm{O}_{7}$ coating. The $\mathrm{La}_{2} \mathrm{Zr}_{2} \mathrm{O}_{7}$ layer was completely delaminated from the dense 8YSZ layer. 


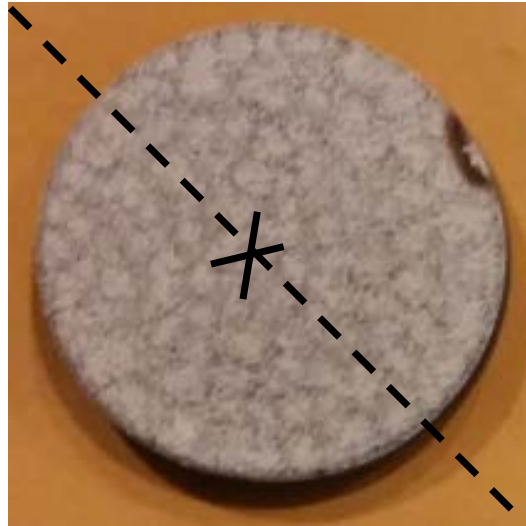

(a)

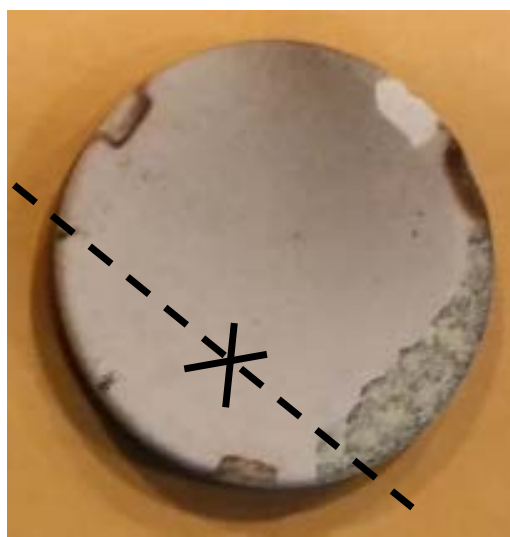

(b)

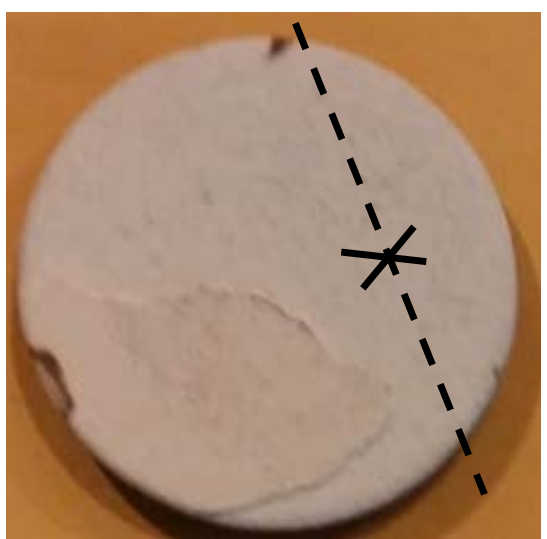

(c)

Figure 2: Optical images of TBCs sample after JETS (a) SCL $\mathrm{La}_{2} \mathrm{Zr}_{2} \mathrm{O}_{7}$; (b) Porous 8YSZ+ $\mathrm{La}_{2} \mathrm{Zr}_{2} \mathrm{O}_{7}$; (c) Dense $8 \mathrm{YSZ}+\mathrm{La}_{2} \mathrm{Zr}_{2} \mathrm{O}_{7}$. The dash line shows the cutting plane of the cross-section view in Figure 3. The cross shows the position where the SEM images were taken in Figure 3.

Figure 3 shows the SEM images of cross-section views of the TBC samples after JETS experiments. The images were taken from the positions shown in Figure 2. For the SCL $\mathrm{La}_{2} \mathrm{Zr}_{2} \mathrm{O}_{7}$ TBC coating (Figure 3a), since the CTE difference between $\mathrm{La}_{2} \mathrm{Zr}_{2} \mathrm{O}_{7}$ layer $\left(9-10 \times 10^{-6}\right.$ $/ \mathrm{K}$ ) and bond coating layer (about $15 \times 10^{-6} / \mathrm{K}$ ) is large, there is a relatively large volume mismatch between $\mathrm{La}_{2} \mathrm{Zr}_{2} \mathrm{O}_{7}$ layer and bond coat [10]. In addition, the fracture toughness of $\mathrm{La}_{2} \mathrm{Zr}_{2} \mathrm{O}_{7}$ is low. So SCL $\mathrm{La}_{2} \mathrm{Zr}_{2} \mathrm{O}_{7}$ sample tends to delaminate near the interface between $\mathrm{La}_{2} \mathrm{Zr}_{2} \mathrm{O}_{7}$ and bond coat. Figure $3 \mathrm{~b}$ shows that the DCL porous $8 \mathrm{YSZ} / \mathrm{La}_{2} \mathrm{Zr}_{2} \mathrm{O}_{7}$ sample was intact after 2000 JETS cycles. The porous 8YSZ layer provides strain compliance due to its high porosity. Figure 3c shows that the DCL dense $8 \mathrm{YSZ} / \mathrm{La}_{2} \mathrm{Zr}_{2} \mathrm{O}_{7}$ sample was fully delaminated at the interface between $\mathrm{La}_{2} \mathrm{Zr}_{2} \mathrm{O}_{7}$ layer and dense $8 \mathrm{YSZ}$ layer. The delamination is caused by the thermal residual stress induced by CTE difference between $\mathrm{La}_{2} \mathrm{Zr}_{2} \mathrm{O}_{7}$ and $8 \mathrm{YSZ}$. In summary, the DCL porous 8YSZ/La $\mathrm{Zr}_{2} \mathrm{O}_{7}$ sample had a better performance in JETS experiments than the DCL dense $8 \mathrm{YSZ} / \mathrm{La}_{2} \mathrm{Zr}_{2} \mathrm{O}_{7}$ and SCL $\mathrm{La}_{2} \mathrm{Zr}_{2} \mathrm{O}_{7}$ samples. 


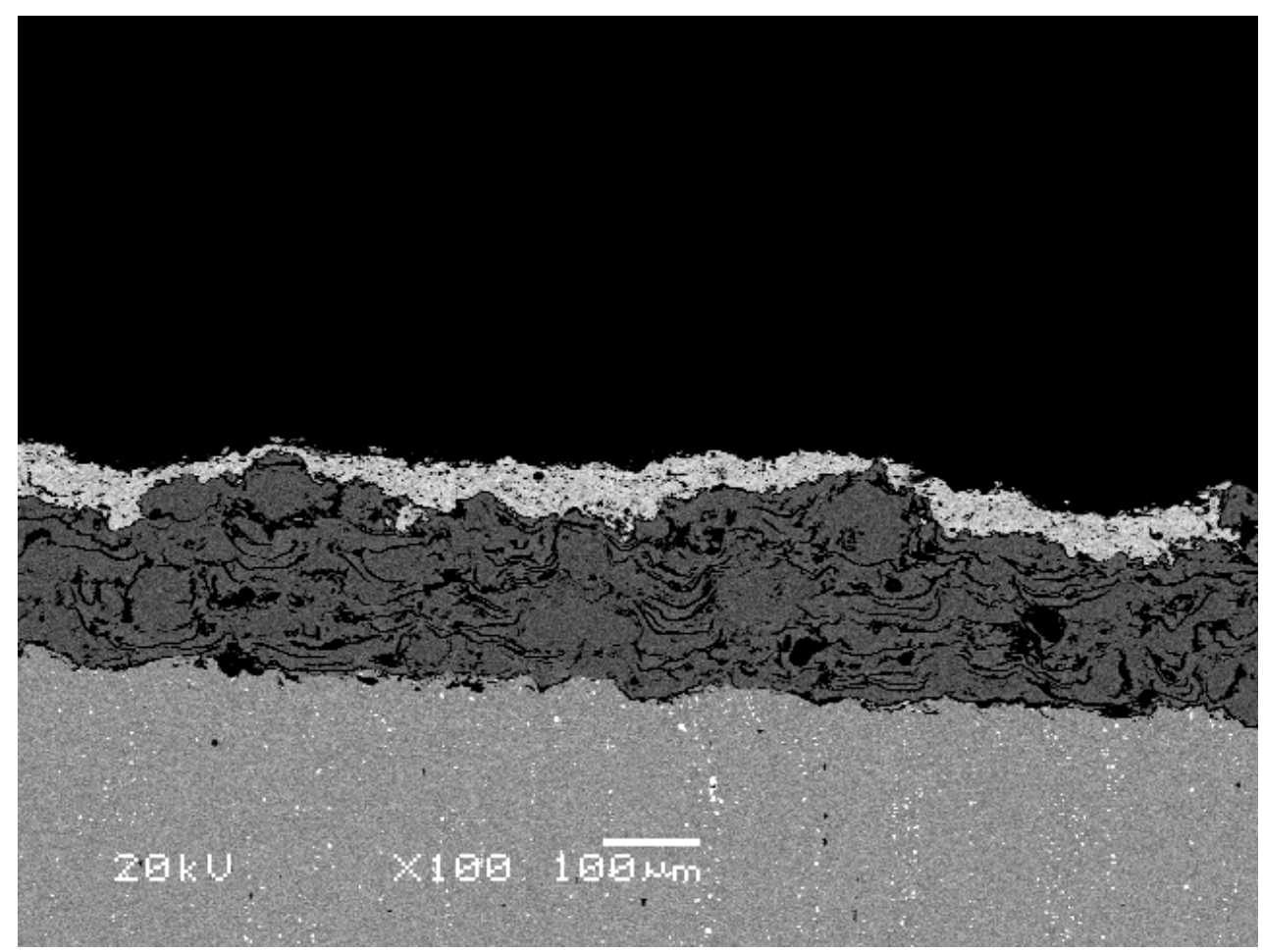

(a)

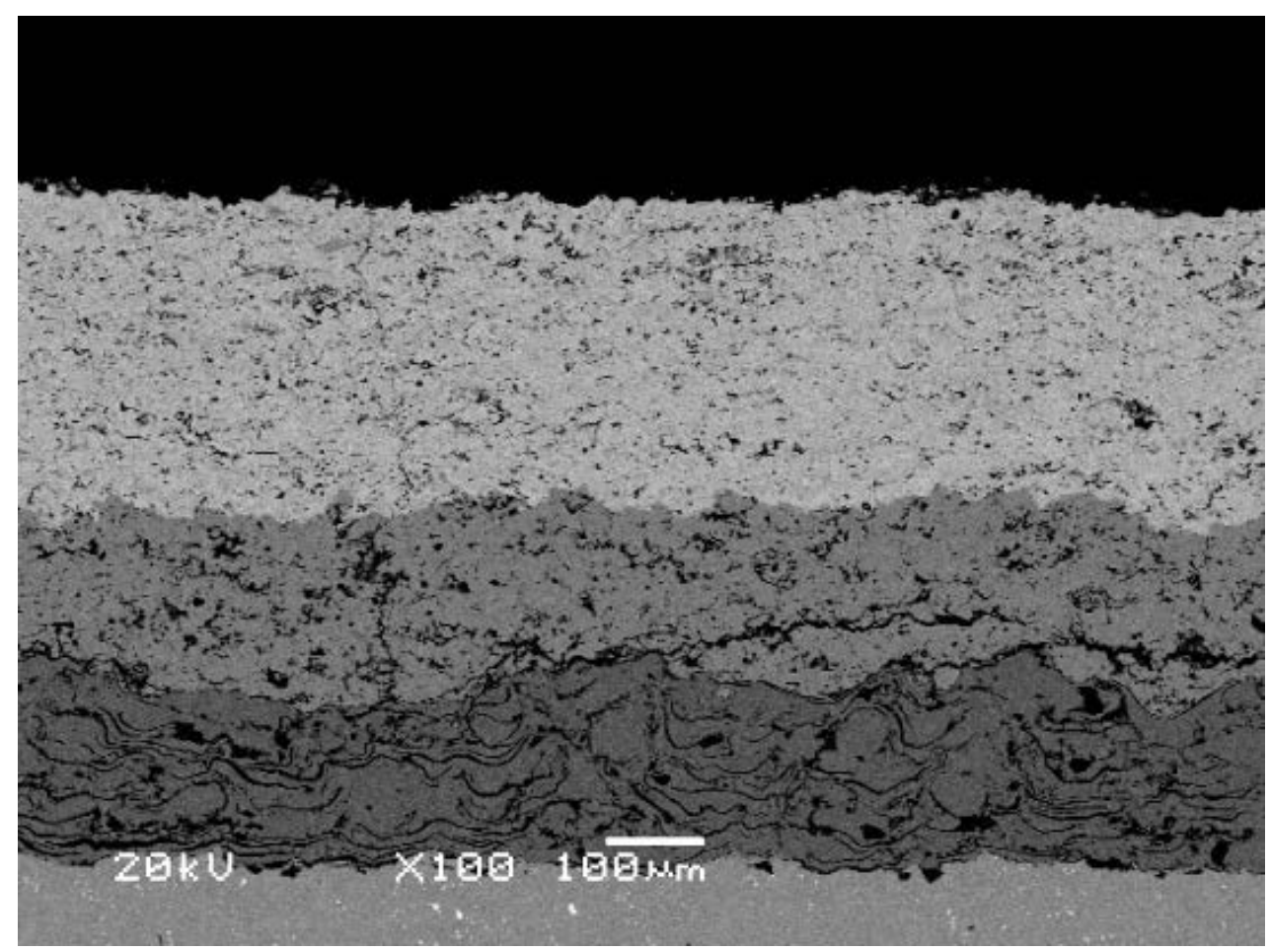

(b) 


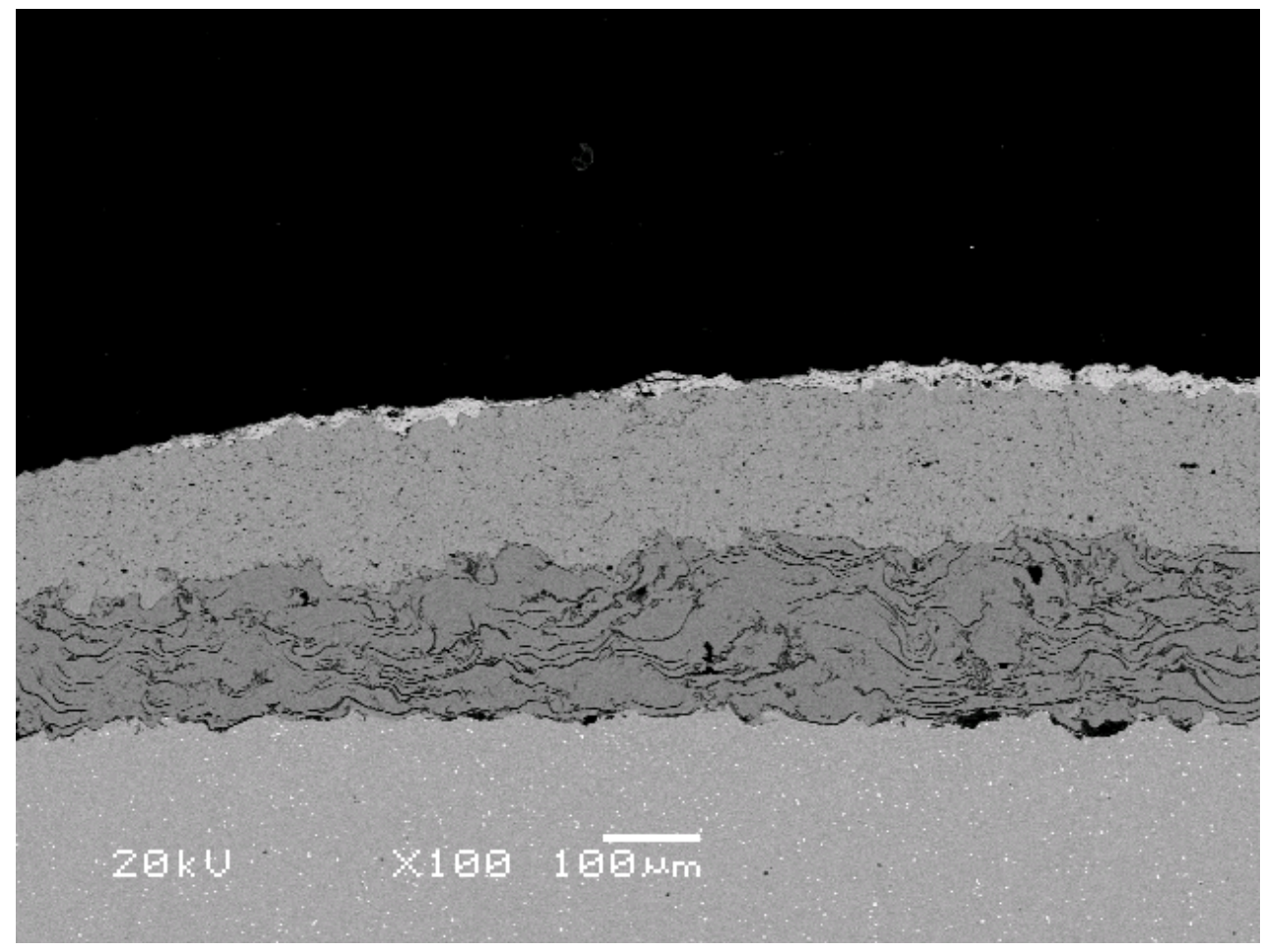

(c)

Figure 3: SEM images of (a) Interface $\mathrm{La}_{2} \mathrm{Zr}_{2} \mathrm{O}_{7}$ and bond coat, (b) Interface $\mathrm{La}_{2} \mathrm{Zr}_{2} \mathrm{O}_{7}$ and porous $8 \mathrm{YSZ}$, (c) Interface $\mathrm{La}_{2} \mathrm{Zr}_{2} \mathrm{O}_{7}$ and dense $8 \mathrm{YSZ}$

\section{CONCLUSIONS}

The thermal stabilities of SCL $\mathrm{La}_{2} \mathrm{Zr}_{2} \mathrm{O}_{7}$, DCL porous $8 \mathrm{YSZ} / \mathrm{La}_{2} \mathrm{Zr}_{2} \mathrm{O}_{7}$ and dense $8 \mathrm{YSZ} / \mathrm{La}_{2} \mathrm{Zr}_{2} \mathrm{O}_{7}$ samples were investigated using heat treatment, FCT and JETS tests. The conclusions are summarized as follows:

1. After 4 hours of heat treatment, the SCL $\mathrm{La}_{2} \mathrm{Zr}_{2} \mathrm{O}_{7}$ and DCL dense $8 Y S Z / \mathrm{La}_{2} \mathrm{Zr}_{2} \mathrm{O}_{7}$ coatings were fully delaminated. In contrast, the DCL porous $8 \mathrm{YSZ}^{2} \mathrm{La}_{2} \mathrm{Zr}_{2} \mathrm{O}_{7}$ coating sample only partially delaminated on the edge. Porous $8 Y S Z$ has a similar CTE as $\mathrm{La}_{2} \mathrm{Zr}_{2} \mathrm{O}_{7}$. As a result, the thermal stress between $\mathrm{La}_{2} \mathrm{Zr}_{2} \mathrm{O}_{7}$ and porous $8 \mathrm{YSZ}$ is low.

2. All the $\mathrm{La}_{2} \mathrm{Zr}_{2} \mathrm{O}_{7}$ coats were delaminated in the furnace cycle test in less than 20 cycles. This is because residual thermal stresses accumulated during thermal cycling.

3. In the JETS experiments, both the SCL $\mathrm{La}_{2} \mathrm{Zr}_{2} \mathrm{O}_{7}$ and DCL dense $8 \mathrm{YSZ} / \mathrm{La}_{2} \mathrm{Zr}_{2} \mathrm{O}_{7}$ coatings were fully delaminated. In contrast, the DCL porous $8 \mathrm{YSZ} / \mathrm{La}_{2} \mathrm{Zr}_{2} \mathrm{O}_{7}$ coating sample only partially delaminated on the edge. This is because of the porous 8YSZ layer provides strain compliance. The results are consistent with the heat treatment data, which shows that the DCL porous $8 \mathrm{YSZ} / \mathrm{La}_{2} \mathrm{Zr}_{2} \mathrm{O}_{7}$ coating has the best thermal stability. 


\section{REFERENCES}

[1] D. R. Clarke, M. Oechsner, and N. P. Padture, "Thermal-barrier coatings for more efficient gas-turbine engines," MRS Bulletin, vol. 37, pp. 891-898, 2012.

[2] D. Clarke and C. Levi, "Materials design for the next generation thermal barrier coatings," Annual Review of Materials Research, vol. 33, pp. 383-417, 2003.

[3] R. Vaßen, M. O. Jarligo, T. Steinke, D. E. Mack, and D. Stöver, "Overview on advanced thermal barrier coatings," Surface and Coatings Technology, vol. 205, pp. 938-942, 11/15/ 2010.

[4] R. A. Miller, "Current status of thermal barrier coatings - An overview," Surface and Coatings Technology, vol. 30, pp. 1-11, 1987.

[5] J. R. Davis, Handbook of thermal spray technology. ASM international, 2004.

[6] R. Vassen, X. Cao, and F. Tietz, "Zirconates as New Materials for Thermal Barrier Coatings," J. Am. Ceram. Soc.,, vol. 83, pp. 2023-2028, 2000.

[7] X. Q. Cao, R. Vassen, and D. Stoever, "Ceramic materials for thermal barrier coatings," Journal of the European Ceramic Society, vol. 24, pp. 1-10, 2004.

[8] R. Vassen, X. Cao, F. Tietz, D. Basu, and D. Stöver, "Zirconates as New Materials for Thermal Barrier Coatings," Journal of the American Ceramic Society, vol. 83, pp. 20232028, 2000.

[9] F. H. Brown and P. O. L. Duwez, "The Systems Zirconia-Lanthana and ZirconiaNeodymia," Journal of the American Ceramic Society, vol. 38, pp. 95-101, 1955.

[10] R. Vaßen, F. Traeger, and D. Stöver, "New Thermal Barrier Coatings Based on Pyrochlore/YSZ DCL Systems," International Journal of Applied Ceramic Technology, vol. 1, pp. 351-361, 2004.

[11] J. Feng, B. Xiao, R. Zhou, W. Pan, and D. R. Clarke, "Anisotropic elastic and thermal properties of the double perovskite slab-rock salt layer Ln2SrAl2O7 (Ln\&\#xa0;=\&\#xa0;La, Nd, Sm, Eu, Gd or Dy) natural superlattice structure," Acta Materialia, vol. 60, pp. 3380-3392, 5// 2012.

[12] K. Bobzin, N. Bagcivan, T. Brögelmann, and B. Yildirim, "Influence of temperature on phase stability and thermal conductivity of single- and double-ceramic-layer EB-PVD TBC top coats consisting of 7YSZ, Gd2Zr2O7 and La2Zr2O7," Surface and Coatings Technology, vol. 237, pp. 56-64, 12/25/ 2013.

[13] X. Q. Cao, R. Vassen, W. Jungen, S. Schwartz, F. Tietz, and D. Stöver, "Thermal Stability of Lanthanum Zirconate Plasma-Sprayed Coating," Journal of the American Ceramic Society, vol. 84, pp. 2086-2090, 2001.

[14] D. Zhu, N. P. Bansal, and R. A. Miller, "Thermal Conductivity and Stability of HfO2Y2O3 and La2Zr2O7 Evaluated for $1650 \mathrm{C}$ Thermal/Environmental Barrier Coating Applications," in Proceedings of the 105th Annual Meeting and Exposition of the American Ceramic Society, The American Ceramic Society, Nashville, TN, 2003.

[15] T. Taylor, "Testing of stability and thermal properties of thermal barrier coatings," $A S M$ International, Member/Customer Service Center, Materials Park, OH 44073-0002, USA, 1994., pp. 654-659, 1994.

[16] A. Bolcavage, A. Feuerstein, J. Foster, and P. Moore, "Thermal shock testing of thermal barrier coating/bondcoat systems," Journal of Materials Engineering and Performance, vol. 13, pp. 389-397, 2004/08/01 2004.

[17] H. Lehmann, D. Pitzer, G. Pracht, R. Vassen, and D. Stöver, "Thermal Conductivity and Thermal Expansion Coefficients of the Lanthanum Rare-Earth-Element Zirconate System," Journal of the American Ceramic Society, vol. 86, pp. 1338-1344, 2003. 
[18] G. K. Beshish, C. W. Florey, F. J. Worzala, and W. J. Lenling, "Fracture toughness of thermal spray ceramic coatings determined by the indentation technique," Journal of Thermal Spray Technology, vol. 2, pp. 35-38, 1993/03/01 1993.

[19] A. G. Evans, D. R. Mumm, J. W. Hutchinson, G. H. Meier, and F. S. Pettit, "Mechanisms controlling the durability of thermal barrier coatings," Progress in Materials Science, vol. 46, pp. 505-553, 2001. 